\title{
Why Do We Go to the Cemetery? Religion, Civicness, and the Cult of the Dead in Twenty-First Century Italy
}

\author{
Asher D. Colombo ${ }^{1,2}$ [ $\cdot$ Eleonora Vlach ${ }^{3}(\mathbb{0}$
}

Received: 28 April 2020 / Accepted: 29 March 2021 / Published online: 26 April 2021

(c) The Author(s) 2021

\begin{abstract}
Background While attitudes towards death and dying have attracted much scholarly attention, surprisingly little is known about the practice of visiting cemeteries. According to the secularization thesis, the fate of cemetery visits conforms with declining church attendance. A de-secularization theory suggests that, in the modern world, cemeteries increasingly became spaces for a society of families rather than for a religious community, suggesting that visiting the tombs of the dead might grow alongside secularization. Finally, a 'civic community' theory, inspired by Putnam's work, sees cemetery visits as an expression of a social obligation among and across generations rather than a religious activity.

Purpose Analyzing one of the least secular countries in Europe, Italy, we attempt to respond to an apparent paradox: Why is the share of people paying tribute to their deceased loved ones at cemeteries in areas of greater secularization higher than in more religious areas?

Methods We take advantage of a rich time use dataset from a representative sample of Italian families surveyed in 2013. To test our hypotheses, we run a series of nested logistic regressions for the probability of visiting the cemetery, jointly considering both individual and contextual features.

Results Our results confirm that individual religiosity is a pivotal predictor of cemetery visits. Yet, even after controlling for religiosity, the probability of visiting a cemetery remains higher among people living in the more secularized part of the country. Our models show that one important reason for this divide is the different level of civicness, here measured at province level. Hence, net of individual religiosity, the frequency of cemetery visits increases with level of civicness in a community.
\end{abstract}

Conclusions and Implications If religious people visit cemeteries in order to pray for the dead, our results also provide support for the hypothesis that the non-religious people living in civic societies visit cemeteries as way to connect with past generations and with their own communities. Our results are thus consistent with the civicness hypothesis, with the caveat that religion and civicness do not seem to cancel each other out.

Extended author information available on the last page of the article 
Keywords Cemetery visits $\cdot$ Secularization $\cdot$ Religiosity $\cdot$ Civicness $\cdot$ Cult of the dead $\cdot$ Italy

\section{Introduction: An Intriguing Enigma}

For a long time, in Europe, visits to cemeteries and the tombs of the dead served two different purposes: 'Ora pro nobis' and 'Memento Mori' (Ariès 1977; Rugg 2000). The first expression reflects the notion that if one prays for the dead one affirms a devotional precept. The second instead evokes the idea that upon remembering that one is mortal, one also recalls that once dead people were alive. Hence, a visit to the cemetery and remembrance of the dead is a way to confirm the link between life and death, and a tribute to a grave recalls the connection between the living and the dead. Indeed, of these two intertwined reasons for visiting the cemetery, only the first is purely religious, while the second is social and underlines connections among and across generations. ${ }^{1}$ Indeed the first of these two reasons has to do with the aim of validating the religious beliefs people have about death, while the second has to do with the connections between the living and their ancestors. These two broader ideas about why people go to cemeteries correspond to the two primary ways people have been developing and continue to use in order to cope with death, namely the religious notion of a soul that continues after death, and the idea that any individual is part of an ancestral line that extends back into the past and forward into the future (Moore 2019). Related to this last idea is the notion that, just as I remember my deceased, so too will I be remembered by my family and friends (sometimes even by my work), extending my spiritual life beyond my physical one.

Yet a significant proportion of the population in Europe now defines themselves as unaffiliated. Beyond that, the last century has seen a steady decline, even among believers, in participation in religious rites and practices, including going to places of worship and praying. ${ }^{2}$ More than that, even among believers, religious life is becoming less and less institutionalized and increasingly private. This shift raises questions not only about the role of religion in daily life, but also about changes in the relationship between religion and its associated beliefs, including those relative to death.

\footnotetext{
${ }^{1}$ Obviously these two motives do not cover all the functions neither of the cemetery-other uses include a hygienic function, and sometimes a marking of social status (see Arffmann 2000) - nor of the visits to the cemetery, which include recreation, relaxations, reflection, contemplation and so on (Erenson et al. 2017; Nordh et al. 2017; Sloane 2018).

${ }^{2}$ There is of course a huge literature on changing behavior relative to religion. The most up-to-date figures are published by the Pew Research Center (2018), and a broad theoretical framework can be found, among others, in Norris and Inglehart (2011).
} 
Consider one of the most religious countries in Europe-in terms of mass attendance and religious affiliation, even if both are declining-Italy. ${ }^{3}$ According to time use survey data, today only a small, and declining, portion of Italians regularly visits the cemetery. As in many other Catholic countries, visits to graves are still rather widespread only during the celebration of the 'Commemorazione dei defunti (All Souls' Day)'. But a detailed look at the pattern of cemetery visits reveals an enigma: the tradition of visiting the dead is less abided by in areas where the level of religiosity-here defined in terms of religious practice, measured by the number of people who attend Mass at least either once a week or once a year in the last twelve months, and in terms of level of obedience to religious precepts, measured by the incidence of religious celebrations on the total number of weddings-is higher (Table 1). ${ }^{4}$ This pattern suggests a disconnection between the two reasons for visiting the cemetery described above.

The aim of this article is to disentangle the conundrum whereby people from more secular places visit cemeteries more often than those living in more religious regions. Italy provides a particularly interesting case of study, given both a strong divide in levels of religious practice and affiliation within the country, and the relative lack of research aimed at solving this puzzling question.

\section{Literature and Hypotheses}

While attitudes towards death and dying have attracted much scholarly attention, surprisingly little is known about the important practice of visiting the cemetery (Boyle 2003; Roberts 2005: 62). Research in this field is far from systematic, with contributions coming from a variety of disciplines and using a range of approaches. Providing any conclusive statements or outlining a precise and cumulative review of the literature thus represents a significant challenge. In what follows, we construct three hypotheses derived from a broad range of literature, at different levels of abstraction.

A first hypothesis is consistent with the framework of the classic version of the secularization theory. Rooted in the work of Weber and Durkheim, and eventually

\footnotetext{
3 Italy is second only to Ireland, according to the percentage of people who attend religious services at least once a week-Atlas of European Values, www.atlasofeuropeanvalues.eu, 2011, visited May 2, 2018. Italy is, however, the only country in Europe where the proportion of people who define themselves as Christian but non-practicing, or who go to Church only occasionally during the year, is smaller than the proportion who report that they are Christian and practicing, or who go to Church at least once a month (Pew Research Center 2018: 6-7). Finally, considering the proportion of baptized children according to the data of Catholic clergy, Italy ranks fourth after Ireland, Poland and Croatia, with a rate far above that of France, Spain, Hungary and the European average (75,3 vs. 38,4 among 0-7 year old children in 2014; authors' calculation on the Annuarium Statisticum Ecclesiae, Libreria Editrice Vaticana, various years). On recent changes in religious beliefs and participation in Italy see, among others: (Bichi e Rovati 2020; Biolcati et al. 2020; Diotallevi 2002; Garelli 2020; Introvigne e Stark 2005; Marzano 2014; Molteni et al. 2020; Pisati 2000; Vezzoni e Biolcati-Rinaldi 2015).

${ }^{4}$ On the differences in religiosity in the Italian regions see, among others (Cesareo et al. 1995; Garelli 2014: 36; 40-42; 46; 55; 60-63; 65, 2020: 69).
} 
Table 1 Distribution of religious behaviors according to geographical area of residence

\begin{tabular}{llcr}
\hline & North and center & South and Islands & Italy \\
\hline Visiting the cemetery* & 2.20 & 0.91 & 1.75 \\
Attending Mass at least once a week $* *$ & 28.8 & 35.0 & 30.5 \\
Attending Mass at least once a year** & 74.9 & 85.2 & 78.8 \\
Religious wedding*** & 46.1 & 73.8 & 57.5 \\
\hline
\end{tabular}

*Percentage of individuals who recorded a visit to the cemetery in their time-diaries independent of the day. ISTAT-UdT 2013

**Percentage of individuals who attended Mass either once a week or more, or at least once in the last 12 months. 2013 ISTAT-Multiscopo

***Percentage of individuals who celebrated a religious wedding instead of a civil ceremony on the total number of weddings in 2013. ISTAT-Matrimoni ${ }^{1}$

becoming one of sociology's most accepted theories beginning in the 1960s (Wilson 1966; Berger 1967, 1969; Luckmann 1967), secularization theory has now become one of its most controversial ideas (Stark 1999; Berger 1999, 2012; Finke and Stark 2005; Berger et al. 2008; Gorski 2008; Norris and Inglehart 2011; Brunn and Gilbreath 2015). Secularization has been defined in a variety of different ways by the social scientists. By this term, we refer to a decline in belief and/or practice at the individual or aggregate level (Finke \& Stark 1998; Iannacone et al. 1997; Stark and Finke 2000). The decline in church attendance is one of the most cited dimensions of this pattern, others being regularity of the prayers, belief in God and affiliation to a Church or a denomination. In line with this reasoning, the fate of cemetery visits is perhaps the same as that of church attendance. Hence, we can suppose that variations in time and space of the visits are directly linked to the variation in religious practice and that, the more secularized-in the unidimensional and simple definition accepted-a community is, the less the cemeteries are visited. This is precisely the idea expressed by Goody and Poppi in a paper based on ethnographic research of a cemetery in northern Italy, where is suggested that the commemoration of the dead, of which cemetery visits form a highly significant part, is one of the last barriers to a complete secularization of the life cycle (Goody and Poppi 1994: 150). The literature and data thus bring us to the formulation of a first hypothesis: ${ }^{5}$

H1A: The lower the level of religious service attendance, the lower the number of cemetery visits.

This version of secularization theory seems, however, oversimplified when long term historical analyses are taken into account. Such line of inquiry confirms the existence of a connection between secularization and the cult of the dead, but suggests that the direction of this relationship is actually the opposite of that hypothesized by secularization theorists. According to Ariés, after the fifteenth century, in France the cult of the dead and visits to cemeteries began to grow just when the influence of Catholicism weakened. He also observed that those cemeteries that

\footnotetext{
${ }^{5}$ Data available at http://dati.istat.it/.
} 
were almost abandoned were in the most Catholic areas of the country and that it was the unbelievers who became the most assiduous visitors to the graves of their relatives (Ariés, 1977). The tradition of visiting the cemetery was thus seemingly not linked to religious feelings or practices. Ariés argued that in the modern world, a new line between private and public life had been drawn. Cemeteries were no longer places for the religious community, but spaces for a society of families. Burials now had gravestones, epitaphs, names. Unlike the past, the new social classes no longer sought to be buried near the remains of saints; the new model became the family burial site (Ariès 1977).

According to this line of research, there were two main reasons driving the growing tradition of visiting the cemetery. First, the emergence of civic and national sentiment surrounding places of the dead (Rugg 2000: 208; Wood and Williamson 2003: 19). Indeed, beginning in late eighteenth century in France, England (Rugg 2000: 208), and Italy (Tomasi 2001; Malone 2017), places for the dead shifted from churchyards to suburban cemeteries, and the meaning of memorializing the dead from the spiritual to the civic realm. Second, the status of the cemetery began to change in the symbolic system of the rising bourgeoisie (Laqueur 1993: 186; 2015: passim). This new class no longer used the cemetery as a place to gain holiness or access heaven after death, but rather to celebrate its virtues: family, hard work, business. In addition to religious symbols or references, sculptures in the new monumental cemeteries now expressed marital (and sometimes secular) love, symbols of the main business of the family or of a tycoon; they celebrated friendship, and sometimes conveyed a fear of death, as can attest a visit to the monumental cemetery in Staglieno, Genoa or that in Milan (Malone, 2017).

The role of the secularization is also challenged by historians of cemeteries. Recently, Anderson et al. (2011) find no evidence of secularization in a sample of grave inscriptions in cemeteries in the Midwestern United States, where they, on the contrary, do observe an increase in the use of sacred language. They conclude that secularization may not be as pervasive as previously thought, particularly with respect to death. Research in Belgium similarly confirms that a demand for religious services and cemeteries has not decreased with secularization, always conceived in the simple and unidimensional meaning already reminded (De Spiegeleer and Tyssens 2017). A study in France, one of the most secularized country in the whole Europe, estimated that between 2007 and 2014, 79\% of people visited the cemetery at least once a year, and only $15-17 \%$ once a month, and that there was no sign of a decline in visits during the seven-year period examined (Siounandan 2014).

This reflection brings us to a second seemingly counterintuitive statement: while there is a strong relationship between the frequency of cemetery visits and personal level of religious practice, the direction of the effect is reversed. Cemeteries are more for the secular than the religious. A second hypothesis can thus be expressed as:

H1B: The higher the frequency of religious service attendance, the lower the probability of visiting the cemetery. 
As this hypothesis is fully alternative to the first hypothesis, it has the same number.

There is also an old body of research that identifies the cemetery as one of the most important social and cultural institutions of a community. Cemeteries embody a collective representation of basic community beliefs, identity, and values about what a society is, and what kind of people live in it (Lloyd Warner 1959; 280; Dubisch 1989; Foster and Hummel 1995). According to the pioneering work of Lloyd Warner, cemeteries are appropriate places for the meeting of and interaction between the living and the dead because they are, among other things, places where the sacred and profane meet one another.

In line with this reflection, the meaning of grave visits is twofold. In addition to the fulfillment of a religious duty or action, people feel the need to comply with an obligation to family members or kin. Sometimes people even go to the cemetery to visit friends or members of a friend's family. Visiting the cemetery is thus a behavior that produces and reinforces family relationships and social networks. ${ }^{6}$

Ethnographic research conducted in London shows that even among people from different religious backgrounds, the cemetery visit is associated with the notion that deceased relatives are members of existing families. ${ }^{7}$ As such, the mutual obligations between husband and wife, parent and child, etc., continue beyond the grave, and religious duty and familial commitment are the two main reasons for visiting the cemetery (Francis 2003; Francis et al. 1997, 2000, 2001, 2005). Another study in the Netherlands shows that cemetery visits are motivated by both religious festivals and sentiments of filial duty. Such visits are embedded in a 'strong ties' model wherein family and friends of the deceased play a more influential role than the community, and visits are aimed at celebrating the unique and individual characteristics of the deceased (Vanderstraeten 2009, 2014). A study based on a sample survey of randomly selected gravestones in York (U.K.) similarly suggests that commemoration is used to express personal relationships with the dead and affiliation with a social group (Buckham 2003).

From very different points of view and approaches, all of these studies point to the fact that the cemetery visit is a kind of social obligation among and across generations. The level of connectedness is a key component of what Putnam has been calling 'civic community' (Putnam 1993: 15; 2015: 207-ff).

Such behavior could be considered as consistent with 'civic community' theory. According to Putnam, the more civicness within a community, the stronger the ties and commitment among people. Thus, in places where civic community is widespread, people will be more likely to do things that favor others without expecting an immediate reward, only reciprocity. This argument can easily be extended to the topic under examination. Visiting someone in a cemetery is not something that

\footnotetext{
${ }^{6}$ The first 240 of 400 interviews conducted with members of different generations within the same family for the project 'Death, Dying, and Disposal in Italy. Attitudes, Behaviors, Beliefs, Rituals' (https:// site.unibo.it/deathinitaly/en) confirm the practice of uniting, at the cemetery, close family members together with more distant relatives and friends, sometimes even moving from one cemetery to another. Several interviewees explicitly referred to this practice with the word 'tour'.

${ }^{7}$ Note that in Italian the expression for visiting a grave is the same as that used for calling on living people: Vado in visita... (I'm going to visit...).
} 
can be done in return by the deceased. In Putnam words, citing Yogi Berra: 'If you don't go to somebody's funeral, they won't come to yours' [cit. by Putnam 2001: 20]. Visiting the cemetery is, in this way, a radical form of generalized reciprocity, possibly at its most extreme, addressed to both past and future generations. The related hypothesis must thus take into account civic community as a contextual factor, rather than as an individual characteristic. Accordingly, we can hypothesize that:

$\mathrm{H} 2$ : Cemetery visits are a kind of commitment among generations, a form of civic community: the more civicness is widespread within a community, the greater the probability of cemetery visits.

Lastly, there exists relatively little systematic research on personal characteristics and their effect on the probability of visiting the cemetery. Attempts to discern personal determinants of the frequency of cemetery visits are, as of this writing, relatively weak and limited to attitudes, and do not consider individual socio-demographic features. Khalish (1986) and Thorson et al. (1987) both find inconclusive results on the influence of the fear of death on the frequency of cemetery visits among a non-random sample of university students. Yet even in the absence of thorough research on this topic, it seems plausible to think that, beside the contextual characteristics, some personal traits are linked to the probability of what Ruggs call 'pilgrimage'. That said, the aim of this article is to discern the factors behind a counterintuitive pattern: Why are there fewer visits to the cemetery precisely where religious practice is more widespread, and vice-versa? Nonetheless, as personal characteristics (e.g., sex, age, family status etc.) might influence the behavior under examination, we control for these aspects in our models.

\section{Data and Methods}

To test our hypotheses, we employ a unique time use dataset, gathered by the Italian National Statistical Office (Istat) in 2013. The Indagine sull'Uso del Tempo (Time Use Survey, henceforth UdT) is a cross-sectional survey on a representative sample of Italian families. The UdT is unique in that the information was collected not only through traditional survey questionnaires, but also by means of 24-h time diaries. More precisely, each survey participant was given a diary in which they reported their activities in intervals of $10 \mathrm{~min}$, over the course of a given day. The UdT employs a complex two-stage sampling strategy, which ensures representativeness both at the territorial and temporal (day of the week and season) levels. In the first stage, provinces were selected by probability proportional to their population size (with probability equal to one for provinces with the highest population density). In the second stage, families were randomly selected from the population registries, and all members of the chosen families were interviewed (ISTAT 2017). 


\section{Dependent Variable}

Measuring the frequency of cemetery visits, as well as other religious behaviors, poses a methodological challenge. Rossi and Scappini (2012) show, for example, that answers to direct questions about an individual's religious behavior may suffer from social desirability. Thus, during standard surveys, interviewees may be prone to overestimating their attendance of religious celebrations in order to report a 'better' version of themselves (Rossi and Scappini 2012; Castegnaro and Dalla Zuanna 2006). To avoid the risk of upwardly biased estimates, we rely on time diaries for our dependent variable. This allows us to measure whether on a specific day, a particular event, such as a visit to the cemetery, occurred. Our dependent variable is thus a dummy variable that takes a value of one if the interviewee reports a visit to the cemetery on the day of the time diary, and zero otherwise. With respect to measures of the same phenomenon adopted by other surveys, our instrument produces more reliable data, if in lower numbers. ${ }^{8}$

\section{Independent Variables}

In our analyses, we consider two main explanatory variables. The first is the individual's level of religiosity. In line with the discussion above relative to our dependent variable, rather than using self-reported frequency of Mass attendance, we instead compute the actual participation of individuals in religious ceremonies according to their time diaries. More specifically, we created a dummy variable that takes a value of one if, on the day of the diary, the individual reported participating in at least one religious celebration or practice in a place of worship other than a cemetery ${ }^{9}$ and zero otherwise.

Our second explanatory variable is civicness, considered as a feature of the local context in which an individual's life is embedded (in our case the province). To measure civicness, we adopt the index suggested by Cartocci, in line with the work of Putnam (1993; Cartocci 2007). The index is based on four indicators measured at the province level: the diffusion of daily newspapers, the level of electoral participation, the distribution of sport associations, and the diffusion of blood donation. The joint consideration of these aspects results in a civicness index that varies from a minimum of -6.43 to a maximum of 5.47 . This variable, which proved to be

\footnotetext{
${ }^{8}$ With $1.75 \%$ of our sample recording a visit to the cemetery on the day of the time diary, this event may be considered to be relatively rare. In this case, particular attention needs to be paid to the estimation strategy, as standard maximum likelihood may represent only a lower bound of the real probability of Y (King and Zeng 2001). Additional analyses, available upon request, compare all estimates in the main text with those obtained through penalized maximum likelihood estimation (Firth 1993, Heinze and Schemper 2002). The two sets of estimates highly match, supporting the strategy of applying standard logistic regression models to study the probability of visiting the cemetery.

9 Respectively: 'Participation in religious ceremonies' (Partecipazione a cerimonie religiose) and 'Religious practices, functions, and prayers in a place of worship' (Pratica religiosa, funzioni e preghiere in un luogo di culto).
} 
non-linearly related to our dependent variable, was centered on this minimum value and enters our models as second-stage polynomial.

In addition, in our models we control for sex, age, age squared, marital status, family size (number of family members), individual's highest degree of education and employment condition, urbanization level of the municipality (number of inhabitants coded as a categorical variable) and day of the survey (workday, Saturday, or Sunday). The variable measuring geographical area of residence contrasts the more secularized North and Centre of Italy with the more religious South and Islands. As controls at the province level, ${ }^{10}$ we employ: the total number of deaths in the specific year of the interview (which enters the models divided by 1,000 and as a second order polynomial), the total number of inhabitants per square kilometer (both as such and squared) measured by 2011 census data, the percentage of religious weddings celebrated in the province in the year of the interview and the per-capita added value at current prices ${ }^{11}$ divided by 1000 . After eliminating all cases with one missing value for any of the above-mentioned variables, our sample comprises 36,614 individuals aged 15 or older who completed the time diary. Table 2 shows the distribution of these variables in our final sample.

\section{Analytical Strategy}

We test our hypotheses through a series of logistic regressions. To test the hypothesis relative to the role of individual religiosity on the probably of visiting the cemetery, we additionally run a province fixed effects model (using province dummies). This allows us to estimate the influence of our first main explanatory variable at the individual level, net of both all observable and unobservable features of the local context that could bias the estimate.

To test the hypothesis relative to the role of civicness in explaining why a person visits the cemetery, we run a series of nested logistic regressions, clustering the standard errors at the province level in order to correct for the greater similarity of individuals living within the same local context. ${ }^{12}$ As our analytic strategy rests on understanding how selected factors (religiosity and civicness in primis) included subsequently in our models may account for the effect of living in the south on the probability of visiting the cemetery, we compute average marginal effects (AME) for all our estimates. While changes in odds-ratio may simply depend on varying levels of unobserved heterogeneity across models (Allison 1999; Mood 2010), AME are robust to this comparability problem and can thus be interpreted as genuine changes

\footnotetext{
10 All variables at the province level (both the explanatory and the controls) derive from data gathered by the Italian National Statistical Office (ISTAT).

11 Added value is an important component of the GDP. We use the latter instead of total GDP in our models, as data on GDP are unfortunately only available at the regional level (of which provinces are sub-units).

12 As a robustness check, we also computed multilevel regression models with individuals at the first level and provinces at the second level. The results of the multilevel model are very similar to those under discussion (Table S8 in the supplementary materials).
} 
produced by the inclusion of the selected independent variables. ${ }^{13}$ Throughout all our analyses, results have been weighted to take into account the complexity of the sampling design. As individuals are more likely to go to the cemetery (as well as take part in religious ceremonies) on days when they have more disposable time (i.e., non-work days) and/or on holy days of obligations (e.g., Sundays), we also control for the diary day in our models (i.e., workday, Saturday, or Sunday).

\section{Results}

\section{Descriptive Statistics}

With the exception of the 'Day of the Dead', the number of visitors to cemeteries has rapidly declined in Italy, to the point of almost disappearing. From 2002 to 2013 the share of people going to the cemetery on an 'average' Sunday fell from $3.5 \%$ to $2.3 \%$, and on an 'average' workday from 1.5 to $0.8 \%{ }^{14}$ In addition, as shown by the data already presented in the Table 1, the share of people going to the cemetery is lower in the South and in the Islands, and higher in the North and in the Center of Italy. This finding is unexpected in that the general level of religiosity, measured in terms of the frequency of participation in religious ceremonies, is instead (as shown in the same table) higher in the South than in the North. Note that this same pattern is also observable across the North, where religiosity in the northeast is higher than in the much more secular northwest, yet the probability of visiting the cemetery shows precisely the opposite pattern (respectively $2.2 \%$ in the northeast and $2.9 \%$ in the northwest).

\section{Regression Models}

The logistic regression models presented in Table 3 (models 1-3) show the effect of area of residence and religiosity on the probability of visiting the cemetery, after controlling for relevant individual characteristics.

Model 1 shows that, compared to the Center/North, living in the South/Islands of Italy is associated with a lower probability, of 1.3 percentage points, of going to the cemetery, even after controlling for the influence of socio-demographic variables.

A closer look at the model reveals interesting additional factors affecting this behavior. Individuals who are divorced or married but not cohabitating are less likely to visit the cemetery than singles (while as expected widowers are more likely to visit it). The same is true of individuals living in families with more than five members, and for employed compared to the retired. Moreover, as might be

\footnotetext{
${ }^{13}$ Comparability issues arise not only in comparing odds-ratios from nested logistic regressions, but also in comparing logit coefficients as such. As pointed out by Karlson et al. (2012), changes in logit coefficients may in fact depend on rescaling of the variance of the underlying latent dependent variable rather than solely reflecting the inclusion of selected independent variables.

${ }^{14}$ While the 2013 percentage derives from the data used for our analysis, that for 2002 comes from a previous wave of the Time Use Survey, conducted by the Italian National Statistical Office in 2002 by means of a similar methodological strategy.
} 
Table 2 Frequency table of the variables used in the analyses, weighted results

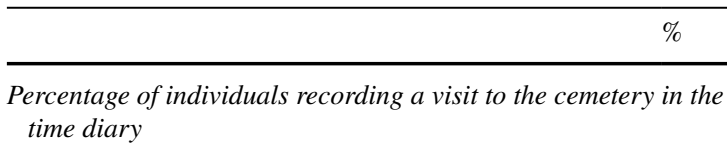
time diary

Yes

No

Percentage of individuals who recorded a religious celebration in the time diary

Yes

No

Geographical area

North and Center

South and Islands

Sex

Male

Female

Age

Mean

Standard deviation

Minimum value 15

$\%$ older than 95 years

0.14

Marital status

Not married or cohabitating

Married and cohabitating

Married not cohabitating

2.92

Legally separated

2.17

Divorced

2.76

Widowed

9.23

Size of family

Single member

2 components

25.59

3 components

25.03

4 components

24.46

5 or more components

9.33

Educational degree

Primary school or less

Lower secondary school

Upper secondary school

36.48

Postsecondary school

Employment condition

Employed

41.14

Looking for employment

Houseworker

Student

9.03

Retired

Other 6.02 
Table 2 (continued)

Urbanization of the municipality

Center of metropolitan area

Periphery of metropolitan area

$>50,000$ inhabitants

Between 50,000 and 10,000 inhabitants

Between 10,000 and 2000 inhabitants

$<2000$ inhabitants

Index of Civicness (province level)

Mean

Standard deviation

3.172

Minimum value

$-6.43$

Maximum value

$\%$ Religious weddings at province level

Mean

Standard deviation

14.74

Minimum value

30.2

Maximum value

87.6

$N$. of deaths at province level

Mean

Standard deviation

$10,372.29$

Minimum value

554

Maximum value

$N$. Inhabitants per $\mathrm{km}^{2}$ at province level

Mean

Standard deviation

Minimum value

30.91

Maximum value

Per-capita added value at province level

Mean

Standard deviation

7,676.43

Minimum value

Maximum value

Day of diary

Workday

Saturday

Sunday

N. of provinces

N. of individuals

36.614

* Number of individuals who recorded a visit to the cemetery in their time-diaries 


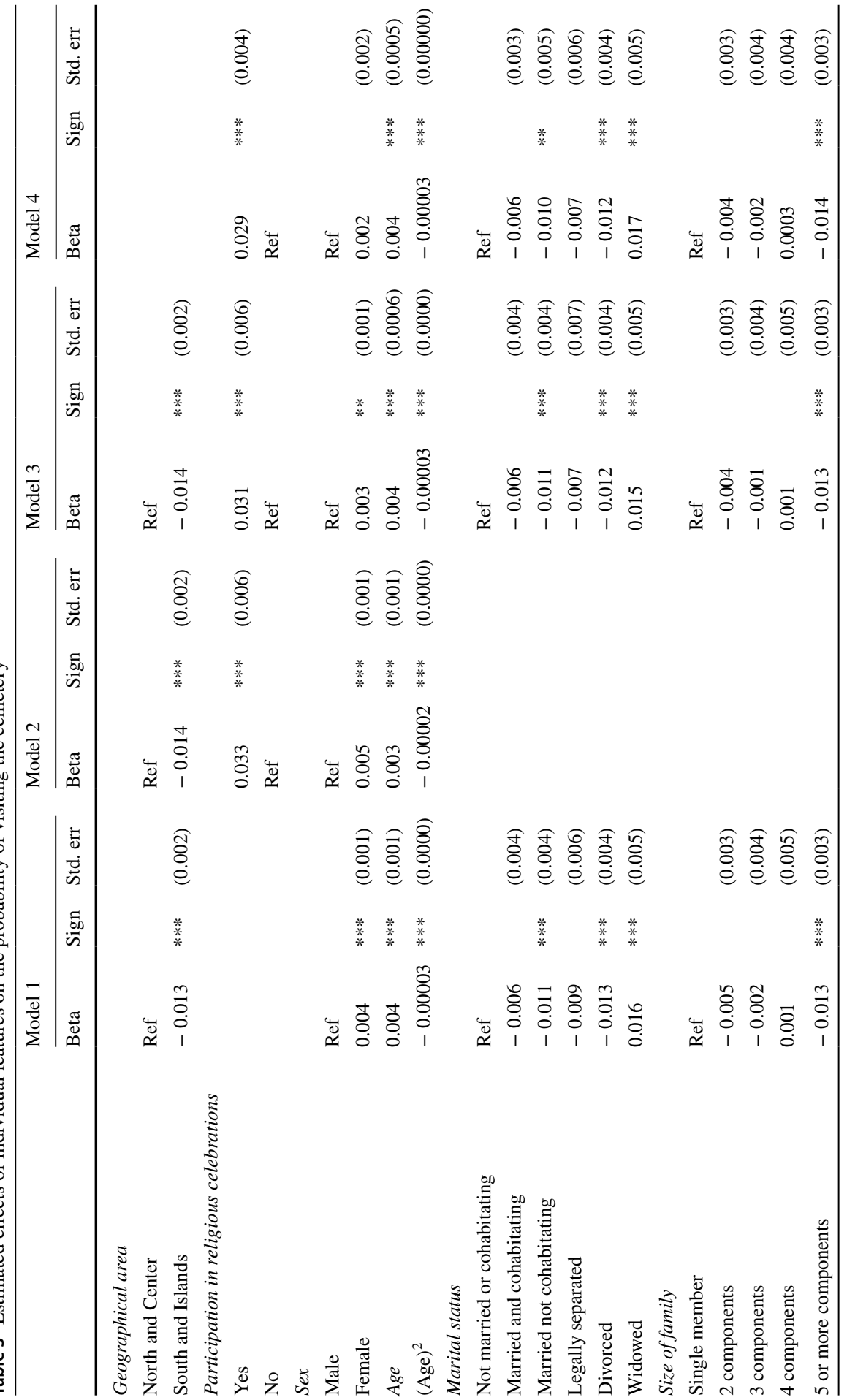




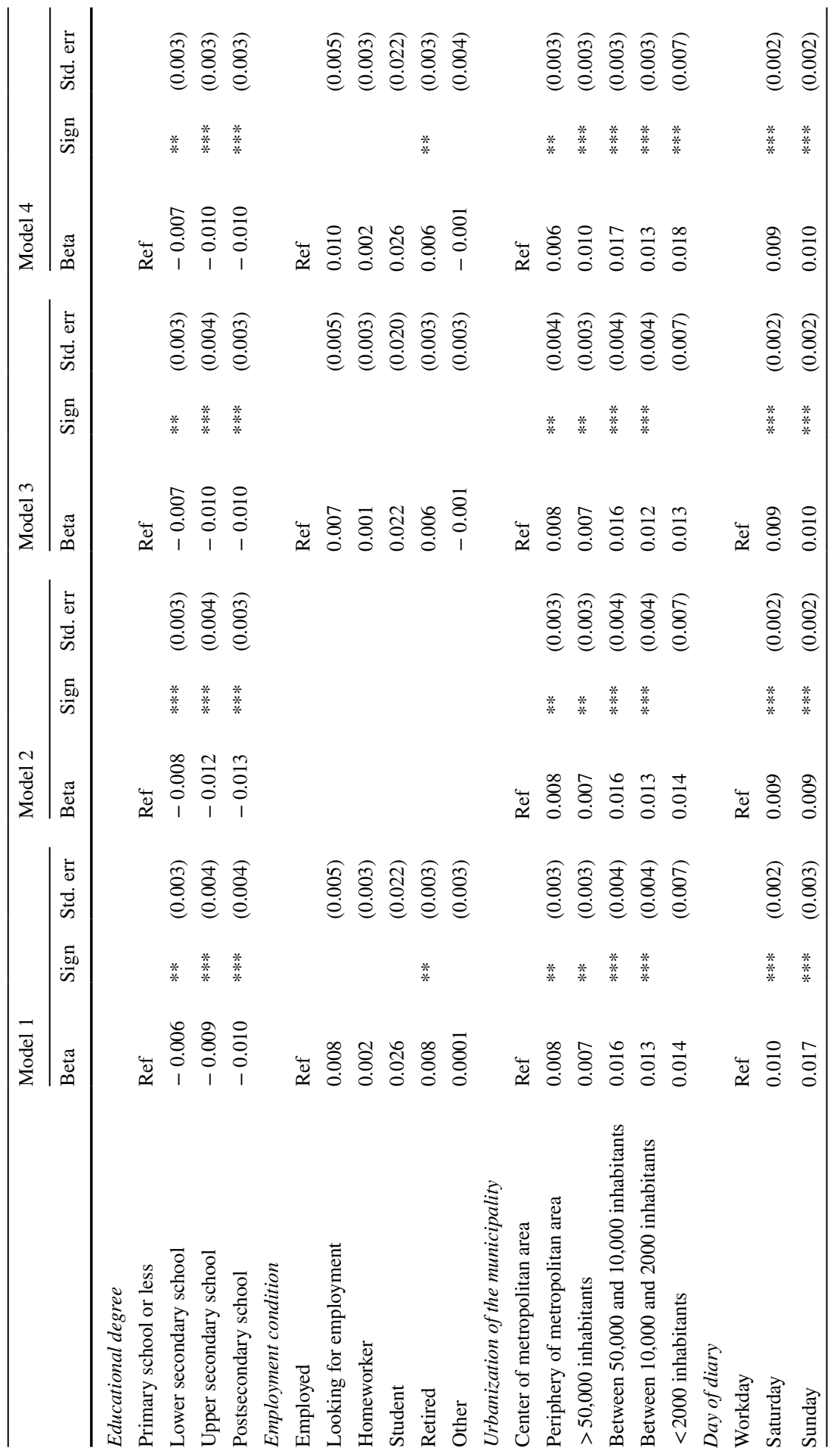




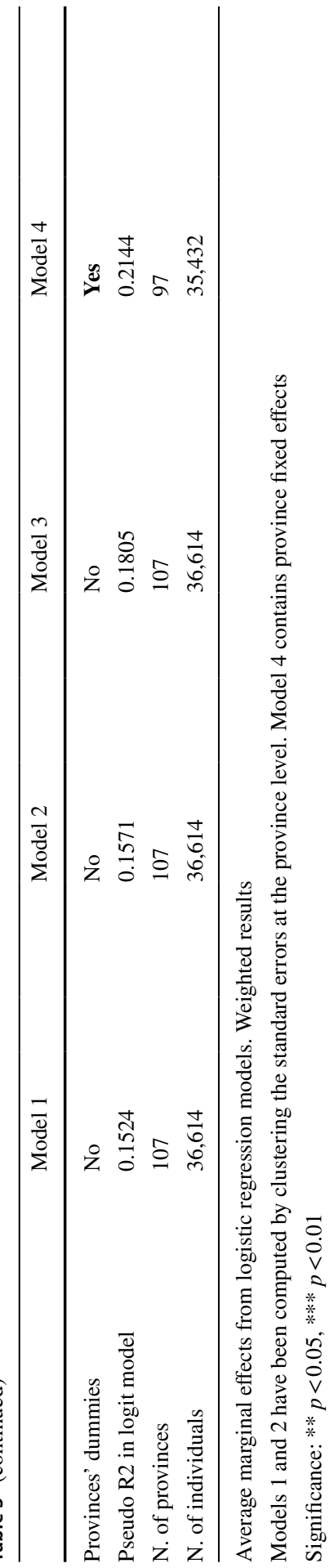


expected, the probability of going to the cemetery is higher on the weekends. This pattern highlights the role of everyday life routines. Visiting the cemetery is a way to confirm one's commitment to the family but also requires time free from work and, paradoxically, from family duties. Hence, high involvement in work and in household related tasks reduces the time available for a not strictly indispensable activity.

Results from model 1 also suggest that cemetery visits are not equally distributed among men and women. Other things being equal, women show a significantly higher propensity to visit the cemetery than men. This is not surprising given the long history of the assignment of 'care' work to women. Moreover, in Italy, as in many other countries, women tend to be more religious than men, such that if religiosity affects the probability of visiting the cemetery, we would expect more women than men visitors.

Also according to model 1 , both level of education and level of urbanization of the municipality in which one lives influence the probability of visiting the cemetery. Indeed, having a higher degree of education and living in a big city are negatively and significantly linked with the probability of visiting the cemetery. Our data thus suggests that residents of urban areas report a lower frequency of visits to the cemetery than inhabitants of non-urban areas. Moreover, while the main effect of the variable age has a positive sign, its squared parameter has a negative one. This reflects the fact that the probability of visiting the cemetery increases with age (of about +0.4 percentages points every additional year), but only up to a certain age, after which the increase first flattens and then reverses. Very old individuals, in fact, are likely to experience issues impeding them from reaching a cemetery (such as an expired driving license, mobility difficulties or chronic illness). ${ }^{15}$

In models 2 and 3 we add our first main explanatory variable: individual level of religiosity. While the parameter for religiosity in model 2 reflects the total effect of the variable on the probability of visiting the cemetery, that in model 3 has to be intended as its direct effect on the dependent variable. Model 3 shows that, after controlling for both the relevant antecedent factors and the intervening variables, individual religiosity level is not only significantly related to the probability of visiting the cemetery but is, in fact, a strong predictor. Indeed, when we add this variable, the overall fit of the model improves decisively with respect to model 1 . The relation between participation in religious ceremonies and propensity to visit the cemetery holds when controlling for age, sex, education, marital status, urbanization level, employment condition, and day of survey. Given the very small proportion of people who regularly visit the cemetery (Table 1), the direct effect of participation in religious celebrations is remarkable. Individuals who take part in religious celebrations show a 3.1 percentage point higher propensity to visit the cemetery than less religious people, other things being equal. This means that there is a positive net effect of religiosity on the individual's propensity to visit the cemetery. So, independent of geographical area of residence, the more likely a person is to attend church, the

\footnotetext{
15 In addition, our models contemporaneously control for both marital status and employment condition (both variables likely to correlate with age), providing us with an estimate for age that has to be considered net of them.
} 
more likely she/he will visit the cemetery. At this stage of analysis, church attendance seems to be the strongest predictor of the behavior under observation. There is still, however, an effect of geographical area of residence on the probability of visiting the cemetery, net of religiosity level. It is further interesting to note the weakening of the effect of sex after adding religiosity level into the model. This result suggests that one of the reasons why more women than men visit the cemetery is linked to the fact that, in general, women are more religious than men.

The results of model 3 are also interesting in that the AME of geographical area of residence on cemetery visits does not decrease: after adding individual level of religiosity, the estimate of the effect of the area of residence is $0.1 \%$ points higher than in model 1.

In model 4 of Table 3 we employ province fixed effects to test whether the effect of individual religiosity on the probability of visiting the cemetery remains when all observable and unobservable characteristics at the province level or above are taken into account. ${ }^{16}$ The difference between the effect of taking part in religious celebrations in model 3 and in model 4 is -0.2 percentage points. We can therefore conclude that part of the effect of religiosity on the probability of visiting the cemetery depends on the specific features of the local context in which an individual lives. Nonetheless, even after controlling for all possible characteristics at the meso-level, the influence of individual level of religiosity in explaining the propensity to visit a cemetery is still positive and statistically significant.

Taken together, these results bring us to reject hypothesis $\mathrm{H} 1 \mathrm{~B}$, which reflects Ariés work on long term changes in attitudes towards death in Europe since the nineteenth century, and which proposes that cemetery visits are more frequent in the more secularized regions of the country because religious people visit cemeteries less often than the non-religious. Instead, we find quite the opposite. Religion is the strongest personal characteristic predicting cemetery visits, as suggested by hypothesis H1A. The models also confirm, however, that people pay their respects to the dead more often in the most secularized part of the country (North/Center) compared to the less secularized area (South/Islands). Hence, although religiosity exhibits a strong positive impact on the probability of visiting the cemetery at the individual level, living in the most religious part of the country has a negative effect. ${ }^{17}$ Consequently, although independent of geographical area of residence religious people visit the cemetery more so than secularized people, the probability of visiting the cemetery is higher in the more secularized compared to the less secularized area of the country. While religion seemingly strengthened visits to the cemetery in a pre-secularized world, once secularization became well-established, other social forces may instead be responsible for pushing people to establish connections with the dead, or at least for slowing the disappearance of the 'pilgrimage'.

\footnotetext{
16 The number of provinces considered in model 4 is 97 instead of 107 as in 10 provinces none of the inhabitants reported visiting the cemetery on the day of the time diary. As a result, the dummy variable of these provinces perfectly predicts the outcome of the dependent variable.

17 Note that the relationship between two variables at the individual level is not necessarily the same as that at the aggregate level. In other words, it should never be assumed that a relationship that holds true at one level will also hold true at another level (Robinson 2009 (1950); Inglehart 2018: 87).
} 


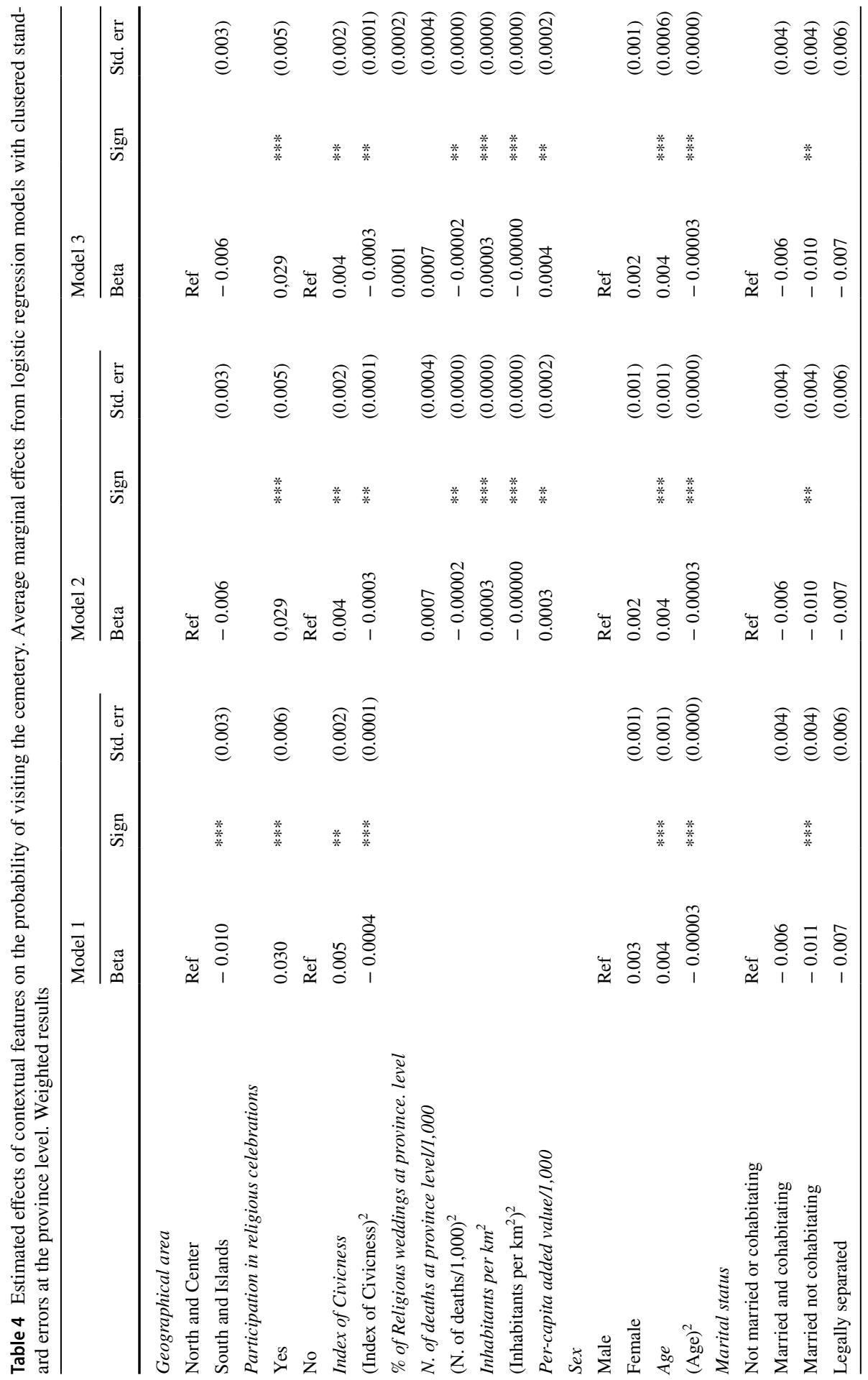




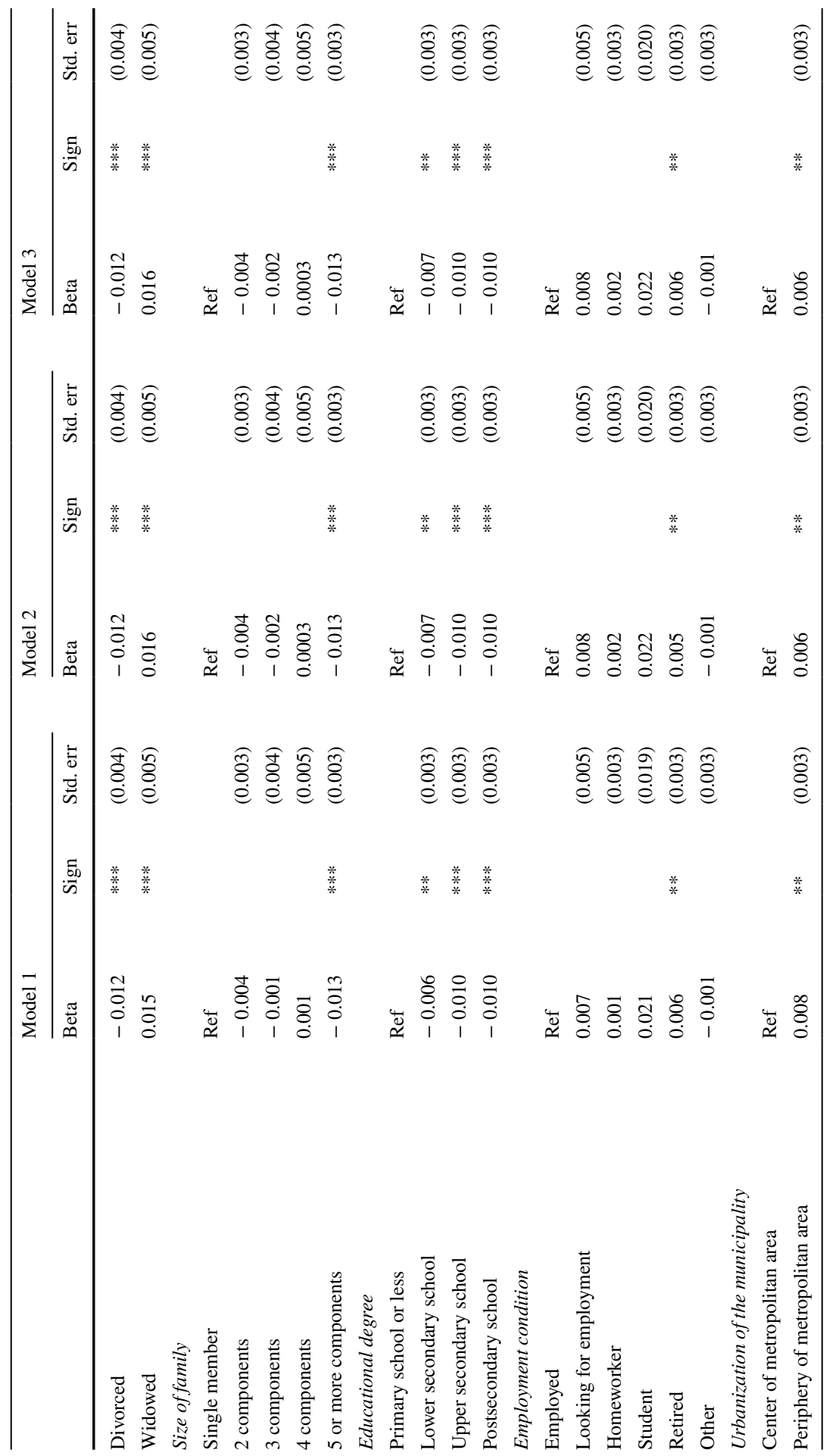




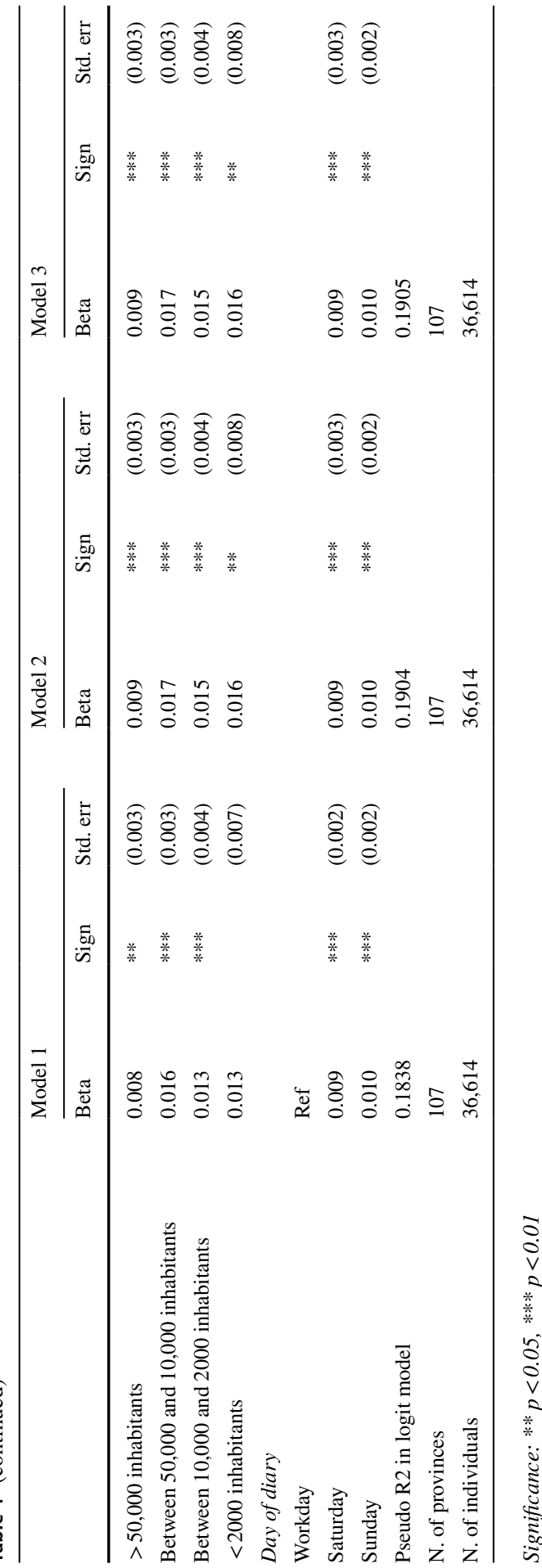


To further our analysis, Table 4 introduces into the model our second explanatory contextual variable: index of civicness. Models 2 and 3 in Table 4 also include a set of structural features of the province, while the model 3 also add an indicator of secularization at the province level (the percentage of religious weddings). The absolute number of deaths is a control for the number of funerals that may have required people to visit the cemetery during the year of the survey. As the number of deaths strongly correlates with the demographic size of the province (Table S1), we also control for population density at the province level in order to disentangle the two aspects in our analyses. Finally, per-capita added value is a measure of economic well-being at the province level. According to the theory of social capital developed by Putnam, the more civicness in a community, the stronger the ties and commitment among people. In contexts where civicness is more widespread, we expect that people will be more likely to do things for others without expecting an immediate reward. Our results show that civicness is significantly correlated with the probability of visiting the cemetery. An increase of one point in the civicness index contributes to a 0.5 percentage point rise in the propensity of going to the burial ground. The significance of the index squared suggests a nonlinear relation of our explanatory variable and the likelihood of visiting the cemetery. This means that the probability of visiting the cemetery grows alongside the growth in civicness, but not up to infinity. At the highest levels of civicness, an increase in the index does not result in any further growth in the probability of visiting the cemetery.

Model 2 adds the structural controls at the province level. Results of model 2 show an even smaller effect for geographical area of residence (now no longer statistically significant), while the significance of civicness remains unaffected. ${ }^{18}$ In model 3 we also add the percentage of religious weddings at the province level, which influence on the probability of visiting the cemetery results to be however non statistically significant and leaves our previous results unaltered. Perhaps the most interesting aspect in the comparison between models before (Table 3) and after the consideration of province-level features (Table 4), concerns the turning of the estimate of the effect of the area of residence from a significant to a non-statistically significant estimate, together with the improvement of the Pseudo $\mathrm{R}^{2}$. This result suggests that we cannot fully explain the probability of visiting the cemetery without taking into account differences in levels of civicness between the Center/North and the South/Islands. In the early 1990s, in his influential book, Putnam argued that institutional performance is shaped much more by 'civicness' than by economic factors, and that the building and collecting of civicness is a long process. Surprisingly, his research also uncovered another puzzling pattern. Civicness has nothing to do with religiosity ${ }^{19}$; rather than a part of civicness, religiosity is instead an alternative to it (Putnam 1993, tr.it. 125-6). The more people practice religion, the less their

\footnotetext{
18 It is interesting to note that net of demographic size of the province, our control for the number of funerals is no longer statistically significant.

19 That is to say, at least in some places. In Bowling Alone. The Collapse and Revival of American Community, Putnam (2001) shows a positive correlation between church attendance and social capital, but only for denominations where internal commitment (bonding) was weaker than external commitment (bridging), i.e., where the religious circle was less central in the life of the citizen than the community.
} 
interest in civic society, meanwhile the more secularized, the more active in polity. Interestingly, this finding has been little investigated in social research.

Given, however, that in our results both civicness at the province level and individual level of religiosity are positively related to the probability of visiting the cemetery, we can conclude that rather than exclude one another, here religion and civicness - together and independently-strengthen the probability of visiting the cemetery.

Our analysis does show that, independent of area of residence, the religious are more likely to visit the cemetery than the secular, although living in the more secularized part of the country has a positive and significant influence on visiting the cemetery. ${ }^{20}$ In this regard, Tables S3 and S4 in the online appendix show the results of a supplementary analysis for the two large geographical divisions of Italy. ${ }^{21}$ Interestingly, in the North/Center of the country (Table S3): (a) participating in religious celebrations increases the probability of visiting the cemetery by 4.1 percentage points, net of all controls at the individual and the province level (second model), and (b) a 1 point upturn in the civicness index seems to increase the likelihood of visiting the cemetery by about 1 percentage point. In the South/Islands (Table S4) taking part in religious celebrations increases the probability of visiting the cemetery by only about 1 percentage point, while the effect of the civicness index is not statistically significant. ${ }^{22}$ This result is consistent with the analysis of the religious precepts in Italian regions made by Ruiu-Breschi. Their research on the Catholic Church's prohibition of celebrating weddings during Lent shows that, in Italy, Southern Regions are less compliant than northern ones, despite the fact that religious marriages are more widespread in the Southern Regions than in the north, a pattern that the two scholars connect to a more "passive" religious observance and a higher strength of the social pressures to conformity in the South against a higher tendency toward respect for religious norms in the northern regions (Ruiu e Breschi 2015). Hence, in the South/Islands, where the share of people visiting the cemetery

\footnotetext{
${ }^{20}$ It is interesting to note that is precisely the level of civicness in the local context in which one is embedded that is the pivotal dimension in this regard. As a robustness check (table S7 in the online appendix), we substitute our civicness variable with measures of individual embeddedness in social networks (the frequency of meeting with friends and the chance to count on others outside the family in case of need, coded as shown in table S6). Neither of these two individual variables influence in any way cemetery visits, nor do they change our results regarding the significant effect of civicness in the local context.

21 The impossibility of relying on large samples once we stratify according to geographical area is a limitation for this ancillary analysis. While our main results obtained from the overall sample clearly show civicness accounting for the effect of the geographical area on the probability of visiting the cemetery (a result that proves to be robust to the variation of the estimation strategy), the reduced sample size in table S3 affects significance levels and expose the model to the source of bias reported by King and Zeng (2001). Estimating the effect of civicness by area through penalized maximum likelihood does not in fact return the same high match found for estimates in the overall sample. While results in tables S3 and S4 need to be interpreted with caution, they do, however, seem to support the interesting findings of the analyses of the overall sample.

22 It should be noted that this result does not seem to depend on a lower inter-province variance of the index of social capital in the South/Islands compared to the North/Center (as shown in Table S5 in the supplementary materials).
} 
is lower, only religiosity seems to have an effect, while in the North/Center, where visiting the cemetery is more common, not only religiosity but civicness too seem to play a role. If in the South only 'Ora pro nobis' pushes people to the cemetery, in the North/Center 'Memento mori' also drives them. As argued above, it thus seems that religion strengthened the likelihood of visiting the cemetery in a pre-secularized world but, once secularization became well-established, other social forces-such as civicness - have also pushed the living to establish connections with the dead, or have at least slowed the weakening of these relationships. ${ }^{23}$ There is a further plausible explanation. After 1990, cremation in Italy started to rise. In 1990 there were only 41 crematoria and 11 cremations per 1000 deaths, while by 2019 the number of crematoria more than doubled, and the cremation rate reached 307 per 1000 deaths. Unfortunately, no administrative data on the place of residence of cremated people are available at territorial level. Due to the fact that the lack of crematoria (just 83 facilities to cover about 600,000 deaths per year) results in an inextricable network of moves back and forth across the country, especially for those residing in the Southern provinces, data on the place of cremation are not fully reliable. Despite that, it is clear that only a very small proportion of cremations took place in the South (Breschi et al. 2018; Colombo 2017). The Catholic Church has long fought cremation, so in Italy the choice of this kind of disposal of the dead has been strongly affected by the level of religiosity, and still is even today. We might, then, reasonably speculate that people go to the cemetery more frequently in the North than in the South due to the fact that, in the North, this behavior is restricted to the less secularized part of the population. It seems very unlikely that people in the most secularized parts of the country don't go to the cemetery simply because their parents are cremated. First, because our models control for religiosity at individual level. Second, because in Italy only a very small proportion of cremated ashes are reposed outside a cemetery. According to a recent survey, based on a random sample of Italian adult population, $80 \%$ of people's parents' remains are kept in a cemetery; exactly the same proportion is confirmed in the analysis of the destination of the ashes of 62,000 cremations conducted in 18 crematoria in northern Italy from 2017 and May 2020 (Colombo 2021). So even those people whose parents were cremated share the same motives to go to the cemetery as those whose parents are buried.

\footnotetext{
${ }^{23}$ The interplay between civic attitudes and religiosity is contentious. According to Putnam, under some circumstances, social capital might be an alternative to religion. This is precisely the case in Italy where, due mainly to historical reasons, "Organized religion, (...) is an alternative to the civic community, not a part of it" (Putnam 1993: 107). More recent research shows that the influence of religiosity on civic attitudes varies from one aspect to another. Religious beliefs have positive effects on trusting other people, respect for the rules, and attitudes toward deviance, but negative effects on attitudes like tolerance towards diversity, gender equality and so on (Guiso et al. 2003). The Pew Research Center reports that religious people tend also to be more engaged in civic life (Pew Research Center 2019).
} 


\section{Conclusion and Implications}

The aim of this study is to investigate an intriguing enigma: Why is the proportion of people who visit cemeteries higher in more secular, as opposed to more religious, areas? The analysis takes advantage of a rich time use dataset on the Catholic country of Italy. A review of the literature produced three hypotheses.

According to the secularization thesis, visits to the cemetery are destined to share the same fate as trips to church: where religiosity decreases, fewer cemetery visits are expected (H1A). The counterintuitive difference between the two main areas of Italy could be due to a disturbing factor.

Some historians argue that while religiosity and visits to the cemetery are linked, the effect is actually the opposite; a sort of modernization effect. Following this line of reasoning, a cult of the dead emerges with the rise of the bourgeoisie, such that we should expect an increase in cemetery visits when religiosity decreases (H1B).

Finally, a recent thread of research suggests that one of the main reasons people visit the cemetery is a commitment among and across generations. We can identify this commitment as a form of social capital. One might accordingly expect that the more the civicness, the greater the frequency of visits to the cemetery $(\mathrm{H} 2)$.

Our results show that, on an individual level, the proportion of people visiting the cemetery is higher among the religious compared to the non-religious. Yet, even after controlling for individual level of religiosity, the probability of visiting a cemetery remains higher among people living in the more secularized part of the country. This divide could partly be explained by different levels of civicness at the province level, or in the two geographical areas, as measured by an integrated index of 'civicness', whereby people in more civic communities are more likely to go to the cemetery than those in less civic communities. If the religious go to the cemetery in order to pray for the dead, our results also provide support for the hypothesis that the non-religious living in civic societies visit the cemetery instead as way to connect with past generations and with their own communities. More generally, our findings suggest that while religion played a role in the memorialization practices of pre-secularized societies, in places where secularization has rooted, other social forcescivicness among them-have slowed the weakening of connections between (and among) the living and the dead.

Our results are most consistent with the civicness hypothesis, with the caveat that religion and civicness do not seem to neutralize one another. The secularization hypothesis is confirmed at the individual level, but not at the territorial level. The modernization thesis is less consistent with the data. However, any conclusions are limited by the scattered and unsystematic nature of the literature in this field. Further work needs to be done on both the empirical and theoretical aspects of memorialization and on the connections between the living and the dead. Moreover, the hypothesis supported here begs further in-depth analysis. Additional research might replicate the study in other countries so as to assess whether the pattern observed here is universal.

Supplementary Information The online version contains supplementary material available at https://doi. org/10.1007/s13644-021-00454-1. 
Acknowledgements The authors would like to thank Raffaele Guetto, Jara Kampmann, Eleonora Mieli, Loris Vergolini and the three anonymous reviewers for their useful suggestions on previous versions of this paper.

Funding Open access funding provided by Alma Mater Studiorum - Università di Bologna within the CRUI-CARE Agreement. This work was supported by the Italian Ministero dell'Istruzione, dell'Università e della Ricerca under Grant 2015FR7MKM.

Open Access This article is licensed under a Creative Commons Attribution 4.0 International License, which permits use, sharing, adaptation, distribution and reproduction in any medium or format, as long as you give appropriate credit to the original author(s) and the source, provide a link to the Creative Commons licence, and indicate if changes were made. The images or other third party material in this article are included in the article's Creative Commons licence, unless indicated otherwise in a credit line to the material. If material is not included in the article's Creative Commons licence and your intended use is not permitted by statutory regulation or exceeds the permitted use, you will need to obtain permission directly from the copyright holder. To view a copy of this licence, visit http://creativecommons.org/licen ses/by/4.0/.

\section{References}

Allison, P.D. 1999. Comparing Logit and Probit Coefficients across Groups. Sociological Methods \& Research 28 (2): 186-208.

Anderson, K.A., C.L. Sielski, E.A. Miles, and A.V. Dunfee. 2011. Gardens of Stone: Searching for Evidence of Secularization and Acceptance of Death in Grave Inscriptions from 1900-2009. OMEGA - Journal of Death and Dying 63 (4): 359-371.

Arffmann, L. 2000. Whose Cemetery? Mortality 5 (2): 125-126.

Ariès, P. 1977. L'homme Devant La Mort. Paris: Seuil.

Berger, P.L. 1967. The Sacred Canopy: Elements of a Sociological Theory of Religion. New York: Doubleday.

Berger, P.L. 1969. The Social Reality of Religion. London: Faber \& Faber.

Berger, P.L. 1999. The Desecularization of the World: Resurgent Religion and World Politics. Grand Rapids, Michigan: William B. Eerdmans Publishing Company.

Berger, P.L. (2012) 'Further Thoughts on Religion and Modernity.' Society, 313-16.

Berger, P.L., G. Davie, and E. Fokas. 2008. Religious America, Secular Europe?: A Theme and Variation. Furnham: Ashgate.

Bichi, R., and G. Rovati. 2020. La religiosità dopo la secolarizzazione. In Come cambiano gli italiani, ed. F. Biolcati, G. Rovati, and P. Segatti, 115. Il Mulino, Bologna: Valori e atteggiamenti dagli anni Ottanta a oggi.

Biolcati, F., R. Ladini, and F. Molteni. 2020. 'Religiosità di ritorno. Una risposta all'incertezza'. Il Regno 12: 341-343.

Boyle, J.E. 2003. Gracing God's Acre. Some Notes on a Typology of Cemetery Visitations in Western Cultures. In Handbook of Death \& Dying, ed. C.D. Bryant, 703-711. CA: Thousand Oaks.

Breschi, M., Ruiu G. and Francini M. (2018). "Ashes to Ashes...”: Could the Recent Evolution of the Cremation Practice in Italy be Interpreted as an Indication of Secularisation?' Review of Religious Research.

Brunn, S.D., and D.A. Gilbreath. 2015. The Changing World Religion Map: Sacred Places, Identities, Practices and Politics. Wiesbaden: Springer VS.

Buckham, S. 2003. Commemoration as an Expression of Personal Relationships and Group Identities: A Case Study of York Cemetery. Mortality 8 (2): 160-175.

Cartocci, R. 2007. Mappe Del Tesoro: Atlante Del Capitale Sociale in Italia. Bologna: Il mulino.

Castegnaro, A., and Zuanna G. Dalla. 2006. Studiare La Pratica Religiosa: Differenze Tra Rilevazione Diretta e Dichiarazione Degli Intervistati Sulla Frequenza Alla Messa. Polis 20 (1): 85-112.

Cesareo, V.R., Garelli F. Cipriani, C. Lanzetti, and G. Rovati. 1995. La religiosità in Italia. Milano: Mondadori. 
Colombo, A.D. 2017. Why Europe Has Never Been United (Not Even in the Afterworld): The Fall and Rise of Cremation in Cities (1876-1939). Death Studies 41 (1): 22-33.

Colombo, A.D. 2021. La solitudine di chi resta. La morte ai tempi del contagio. Bologna: Il Mulino.

De Spiegeleer, C., and J. Tyssens. 2017. Secularizing Funerary Culture in Nineteenth-Century Belgium: A Product of Political and Religious Controversy. Death Studies 41 (1): 14-21.

Diotallevi, L. 2002. Internal Competition in a National Religious Monopoly: The Catholic Effect and the Italian Case. Sociology of Religion 63 (2): 137.

Dubisch, J. 1989. Death and Social Change in Greece. Anthropological Quarterly 62 (4): 189-200.

Finke, R., and R. Stark. 1998. Religious choice and competition. American Sociological Review 63 (5): 761-766.

Finke, R., and R. Stark. 2005. The Churching of America 1776-2005. New Brunswick: Rutgers University Press.

Firth, D. 1993. Bias Reduction of Maximum Likelihood Estimates. Biometrika 80 (1): 27-38.

Foster, G. S. and Hummel R.L. (1995) The Adkins-Woodson Cemetery: A Sociological Examination of Cemeteries as Communities. Markers: The Annual Journal of the Association for Gravestone Studies 11: 92-117.

Francis, D., L. Kellaher, and C. Lee. 1997. Talking to People in Cemeteries. Journal of the Institute of Burial and Cremation Administration 65: 14-25.

Francis, D. 2003. Cemeteries as Cultural Landscapes. Mortality 8 (2): 222-227.

Francis, D., L.A. Kellaher, and G. Neophytou. 2000. Sustaining Cemeteries: The User Perspective. Mortality 5 (1): 34-52.

Francis, D., L.A. Kellaher, and G. Neophytou. 2001. 'The Cemetery: The Evidence of Continuing Bonds.' Grief, Mourning and Death Ritual, pp. 226-36.

Francis, D., Kellaher L.A., and Neophytou G. (2005) The Secret Cemetery. Oxford: Berg Publisher

Garelli, F. (2014) Religion italian Style. Continuities and Changes in a Catholic Country. Ashgate.

Garelli, F. 2020. Gente di poca fede. Il sentimento religioso nell'Italia incerta di Dio. Bologna: Il Mulino.

Goody, J., and C. Poppi. 1994. Flowers and Bones: Approaches to the Dead in Anglo-American and Italian Cemeteries. Comparative Studies in Society and History 36 (1): 146-175.

Guiso, L., Sapienza P. and Zingales L. (2003). 'People's opium?', Religion and economic attitudes. Journal of Monetary Economics 50: 225-282.

Heinze, G., and M. Schemper. 2002. A Solution to the Problem of Separation in Logistic Regression. Statistics in Medicine 21 (16): 2409-2419.

Inglehart, R.F. 2018. Cultural Evolution. People's Motivations Are Changing, and Reshaping the World. Cambridge: Cambridge University Press.

Introvigne, M., and R. Stark. 2005. 'Religious Competition and Revival in Italy: Exploring European Exceptionalism. Interdisciplinary Journal of Research on Religion 1: 1-20.

Istat, . 2017. Aspetti Metodologici Dell'indagine Uso Del Tempo - Periodo Di Riferimento 2013-2014. Roma: Istituto Nazionale di Statistica.

Karlson, K.B., A. Holm, and R. Breen. 2012. 'Comparing Regression Coefficients Between Same-Sample Nested Models Using Logit and Probit: A New Method. Sociological Methodology 42 (1): 286-313.

King, G., and L. Zeng. 2001. Logistic Regression in Rare Events Data. Political Analysis 9 (2): 137-163.

Laqueur, T. (1993) 'Cemeteries, Religion and the Culture of Capitalism.' Revival and Religion Since, $1700(9)$.

Laqueur, T. 2015. The Work of the Dead: A Cultural History of Mortal Remains. Princeton and Oxford: Princeton University Press.

Lloyd Warner, W. 1959. The Living and the Dead: A Study of the Symbolic Life of Americans. New Haven: Yale University Press.

Marzano, M. 2014. Quel che resta dei cattolici. Inchiesta sulla crisi della chiesa in Italia. Milano: Feltrinelli.

Molteni, F., Ladini R., Biolcati F. Chiesi A.M, Dotti Sani G.M., Guglielmi S., Maraffi, M., Pedrazzani A., Segatti P. and Vezzoni C. (2020) 'Searching for comfort in religion: insecurity and religious behaviour during the COVID-19 pandemic in Italy'. European Societies.

Mood, C. 2010. Logistic Regression: Why We Cannot Do What We Think We Can Do, and What We Can Do About It. European Sociological Review 26 (1): 67-82.

Norris, P., and R. Inglehart. 2011. Sacred and Secular: Religion and Politics Worldwide. Cambridge: Cambridge University Press.

Pew Research Center. 2018. Being Christian in Western Europe. https://www.pewresearch.org. 
Pew Research Center. 2019. Religion's relationship to Happiness. Washington, DC: Civic Engagement and Health Around the World.

Pisati, M. 2000. La domenica andando alla messa. Un'analisi metodologica e sostantiva di alcuni dati sulla partecipazione degli italiani alle funzioni religiose. Polis 50 (1): 115-136.

Putnam, R.D. 1993. Making Democracy Work. Princeton University Press.

Putnam, R.D. 2001. Bowling Alone: The Collapse and Revival of American Community. New York: Simon \& Schuster.

Putnam, R.D. 2015. Our Kids: The American Dream in Crisis. New York: Simon \& Schuster.

Roberts, P. 2005. The Living and the Dead: Community in the Virtual Cemetery. OMEGA - Journal of Death and Dying 49 (1): 57-76.

Robinson, W.S. 2009. Ecological Correlations and the Behavior of Individuals. International Journal of Epidemiology 38 (2): 337-341.

Rossi, M., and E. Scappini. 2012. How Should Mass Attendance Be Measured? An Italian Case Study. Quality \& Quantity 46 (6): 1897-1916.

Rugg, J. 2000. Defining the Place of Burial: What Makes a Cemetery a Cemetery? Mortality 5 (3): 259-275.

Ruiu, G., and M. Breschi. 2015. For the Times They are a Changin' - The Respect for Religious Precepts Through the Analysis of the Seasonality of Marriages. Italy, 1862-2012. Demographic Research 33 (1): $179-210$.

Siounandan, N. (2014) La Montée de l'immatériel Dans Les Pratiques Funéraires. CRéDOC.

Sloane, D.C. 2018. Is the Cemetery Dead? Chicago: University of Chicago Press.

Stark, R. 1999. Secularization, R.I.P. Sociology of Religion 60 (3): 249.

Stark, R., and R. Finke. 2000. Acts of Faith: Explaining the Human Side of Religion. Berkeley: University of California Press.

Thorson, J.A., B.J. Horacek, and G. Kara. 1987. A Replication of Kalish's Study of Cemetery Visits. Death Studies 11 (3): 177-182.

Tomasi, G. 2001. Per Salvare I Viventi. Le Origini Settecentesche Del Cimitero Extraurbano., Bologna: Il Mulino.

Vanderstraeten, R. 2009. Modes of Individualisation at Cemeteries. Sociological Research Online 14 (4): 10.

Vanderstraeten, R. 2014. Burying and Remembering the Dead. Memory Studies 7 (4): 457-471.

Vezzoni, C., and F. Biolcati-Rinaldi. 2015. Church Attendance and Religious Change in Italy, 19682010: A Multilevel Analysis of Pooled Datasets. Journal for the Scientific Study of Religion 54 (1): $100-118$.

Wilson, B.R. 1966. Religion in Secular Society. Watts and co: C.A.

Wood, WR. and Williamson, J.B. (2003) 'Historical Changes in the Meaning of Death in the Western Tradition.' in Handbook of Death \& Dying, edited by C. D. Bryant. Sage.

Publisher's Note Springer Nature remains neutral with regard to jurisdictional claims in published maps and institutional affiliations.

\section{Authors and Affiliations}

\section{Asher D. Colombo ${ }^{1,2}\left[\right.$ [ Eleonora Vlach ${ }^{3}$ (]}

Asher D. Colombo

asherdaniel.colombo@unibo.it

1 Department of Political and Social Sciences, University of Bologna, Strada Maggiore 45, 40125 Bologna, Italy

2 Fondazione Di Ricerca Istituto Carlo Cattaneo, Strada Maggiore 37, 40125 Bologna, Italy

3 Faculty of Social Sciences - Institute of Sociology, Goethe-University Frankfurt Am Main, Theodor-W.-Adorno-Platz 6, 60323 Frankfurt am Main, Germany 